DOI:10.14258/tpai(2021)33(3).-14

УДК 903.01(517)

\title{
EMERGENCE OF MICROLITHIC PRODUCTION IN MONGOLIA: RESEARCH TERMINOLOGY AND CHRONSTRATIGRAPHIC POSITION OF LITHIC INDUSTRIES IN EASTERN AND SOUTHERN ASIA
}

\section{Arina M. Khatsenovich', Evgeny P. Rybin', Margad-Erdene Ganbold'2, Dashzeveg Bazargur ${ }^{3}$}

'Institute of Archaeology and Ethnography SB RAS, Novosibirsk, Russian Federation; ${ }^{2}$ Novosibirsk State University, Novosibirsk, Russian Federation; ${ }^{3}$ Institute of Archaeology MAS, Ulaanbaatar, Mongolia

ORCID: https://orcid.org/0000-0002-8093-5716, e-mail: archeomongolia@gmail.com ORCID: https://orcid.org/0000-0001-7434-2757, e-mail: rybep@yandex.ru e-mailm.ganbold@g.nsu.ru

ORCID: https://orcid.org/0000-0003-2183-0591, e-mail: dbazargur_0622@yahoo.com

\begin{abstract}
Territory of Mongolia is situated in the center of Asia, a crossroad of the potential migration routes, that connect different Eurasian macroregions. Here an example of earliest appearance and longterm existence of small blade and microblade production has been found. Beyond that, the industries, that appeared within limited area of the Middle Selenga Basin in the late MIS3 - early MIS2, contained the earliest for Northern and Central Asia geometric and non-geometric microliths. They have been found in the sediments of Kharganyn Gol 5 and Tolbor-4, - 16 and -21. They end up in LGM - postLGM which cause depopulation in the region and following changes in the human groups, occupying this territory. An understanding of the character, causes and specifics of such early appearance of the microblade and bladelet production, and especially geometric microliths, impose the arrangement and definition of the terminology, associated with microlithic assemblages in Asia.

This is due to the fact that in the archaeological definitions of both processes and the desired forms of artifacts associated with the production and use of microliths, there are significant discrepancies that complicate the understanding of the described phenomena. The article provides an overview of the research terminology of microlithization processes, and also determines the position of the microlithic complexes of Mongolia in the Upper Paleolithic system of the eastern part of Asia.

Keywords: Mongolia, East Asia, Upper Paleolithic, lithic industries, microlithic technology

Acknowledgments: The analytical work was completed with the financial support of the Russian Foundation for Basic Research grant No. 19-59-44010 Mong_t, and correlation between Mongolian and Eastern Asian assemblages was supported by IAET NIR project № 0329-2019-0002 “Earliest cultural processes in Central Asia".
\end{abstract}

For citation: Khatsenovich A. M., Rybin E. P., Margad-Erdene G., Bazargur D. Emergence of Microlithic Production in Mongolia: Research Terminology and Chronstratigraphic Position of Lithic Industries in Eastern and Southern Asia. Theory and Practice of Archaeological Research. 2021;33(3): 260-275. (In English) DOI: 10.14258/tpai(2021)33(3).-14 


\title{
ВОЗНИКНОВЕНИЕ МИКРОАИТИЧЕСКОГО ПРОИЗВОАСТВА
} В МОНГОАИИ: ИССАЕАОВАТЕАЬСКАЯ ТЕРМИНОАОГИЯ И ХРОНОСТРАТИГРАФИЧЕСКАЯ ПОЗИЦИЯ ИНАУСТРИЙ В ВЕРХНЕМ ПААЕОАИТЕ ВОСТОЧНОЙ И ЮЖНОЙ ЧАСТИ АЗИИ

\author{
А.М. Хаценович', Е.П. Рыбин', М.-Э. ГанболА², А. Базаргур ${ }^{3}$ \\ 'Институт археологии и этнографрии СО РАН, г. Новосибирск, Российская ФеАерация \\ ${ }^{2}$ Новосибирский государственный университет, г. Новосибирск, Российская Федерация \\ ${ }^{3}$ Институт археологии МАН, г. УАан-Батор, Монголия \\ ORCID: https://orcid.org/0000-0002-8093-5716, e-mail: archeomongolia@gmail.com \\ ORCID: https://orcid.org/0000-0001-7434-2757, e-mail: rybep@yandex.ru \\ e-mailm.ganbold@g.nsu.ru \\ ORCID: https://orcid.org/0000-0003-2183-0591, e-mail: dbazargur_0622@yahoo.com
}

Резюме: На территории Монголии, находящейся в центре Азии на перекрестке потенциальных миграционных путей, связывающих различные макрорегионы Евразии, фиксируется пример раннего возникновения и долгого существования мелкопластинчатой и микропластинчатой традиции расщепления. Кроме того, в конце морской изотопной стадии 3 и начале морской изотопной стадии 2 на ограниченной территории в пределах среднего течения Селенги в седиментах стоянок Толбор-4, 16 и 21 засвидетельствовано наиболее раннее в Центральной Азии появление индустрий, содержащих микролиты. Их существование пресекается в период последнего ледникового максимума, связанного с возможной депопуляцией территории и последующей сменой населения. Понимание характера, причин и особенностей столь раннего появления производства микропластин и пластинок и собственно микролитов требует систематизации и определения терминологии, относящейся к микролитическим ассамбляжам на территории Азии. Это вызвано тем, что в археологических дефинициях как процессов, так и желаемых форм артефактов, связанных с производством и использованием микролитов, существуют значительные разночтения, затрудняющие понимание описываемых явлений. В статье приводится обзор исследовательской терминологии процессов микролитизации, а также определяется положение микролитических комплексов Монголии в системе верхнего палеолита восточной части Азии.

Ключевые слова: Монголия, Восточная Азия, верхний палеолит, каменные индустрии, микролитическая технология

Благодарности: Исследования технологии расщепления монгольских стоянок каменного века выполнены при поддержке гранта РФФИ 19-59-44010 Монг_т «Пустынные земли: смена палеолитических культур в степных и пустынных ландшафтах Монголии во время последнего максимума оледенения плейстоцена и позднего дриаса». Определение позиции микролитических комплексов Монголии в системе плейстоцен-голоценовых комплексов восточной Азии выполнено в рамках проекта НИР № 0329-2019-0002 «Древнейшие культурные процессы на территории Центральной Азии».

Для цитирования: Хаценович А. М., Рыбин Е. П., Ганболд М.-Э., Базаргур Д. Возникновение микролитического производства в Монголии: исследовательская терминология и хроностратиграфическая позиция индустрий в верхнем палеолите восточной и южной части Азии // Теория и практика археологических исследований. 2021. Т. 33, № 3. С. 260-275. DOI: 10.14258/ tpai(2021)33(3).-14 


\section{Tntroduction}

The early origin of pressure microblade production in Asia has always been a controversial issue. Sporadically found early cores for pressure microblade production are the weak evidence of micropressure technique, as well as early appearance of percussion microblade production does not prove its connection with later pressure technology.

The territory of Mongolia is situated in the center of Asia, crossroads of the potential migration routes, that connect different Eurasian macroregions. Here an example of earliest appearance and long-term existence of small blade and microblade production has been found [Gladyshev, 2017; Gladyshev, Tabarev, 2017, 2018]. Beyond that, the industries, that appeared within limited area of the Middle Selenga Basin in the late MIS3 - early MIS2, contained the earliest for Northern and Central Asia geometric and non-geometric microliths. They have been found in the sediments of Kharganyn Gol 5 and Tolbor-4, 16 and -21 . They end up in LGM - post-LGM which cause depopulation in the region and following changes in the human groups, occupying this territory [Mao et al., 2021]. An understanding of the character, causes and specifics of such early appearance of the microblade and bladelet production, and especially geometric microliths, impose the arrangement and definition of the terminology, associated with microlithic assemblages in Asia. Frequently, there are various discrepancies in the archaeological definitions of the processes, byproducts and targeted blanks related to microlith production and utilization which makes it difficult to understand these processes.

Little is known about small-blade or bladelet production in the Upper Paleolithic of eastern Central Asia and southern Siberia before pressure microblade technology first appeared in these regions during or immediately after the LGM. There are also some ambiguities in the statement of small- or microblade technology here. The term "small-blade production" is used by different scholars in different ways. The most widespread definition is the production of small blades [Faivre, 2012], metrically distinct to bladelets by the limit in $12 \mathrm{~mm}$ - the maximal width of blank, determined for Epipaleolithic of Maghreb [Tixier, 1963; Inizan et al., 1999]. But under circumstances when bladelets and small blades were produced within one chaîne opératoire, all end-products are called small-blade blanks [Inizan et al., 1999; Soriano, Villa, Wadley, 2007]. At the same time, Kuhn \& Elston [2002] pointed at the limit of $9 \mathrm{~mm}$ "to distinguish between retouched blades and (microlithic) retouched bladelets in Levant, that wouldn't work in Northeast Asia according to them, where microblades are much smaller. In American archaeology, the width of microblades ranges from 1-11 mm, and blanks wider than $11 \mathrm{~mm}$ are considered as blades [Taylor, 1962; Sollberger, Patterson, 1976]. Japanese archaeology considers the laminar blanks with width less than $12 \mathrm{~mm}$ as the microblades. Many researchers choose the dimension of laminar flakes that traditionally, following Inizan et al. [1999], used for their description in assemblages from Central Asia and Altai, based on the their width: microblades - less than $6 \mathrm{~mm}$, bladelets - from 7 to $12 \mathrm{~mm}$, blades up to $12 \mathrm{~mm}$ [Kolobova et al., 2013; Rybin et al., 2017]. Talking about microblade technology in northeast Asia, where, indeed, the common limit for microblades width is $6 \mathrm{~mm}$, we usually mean pressure technique of this type of blank production, highly standardized, resulted from narrow set of microblade core types and appeared during or after LGM at the continental part of northeastern Asia, and cannot be comparable to percussive bladelets and microliths directly. 
It is a clear example of intricate terminology that we use describing the processes of the small laminar blank production. Here we consider the definitions of the main terminology offered by regional researchers, in the background of the process of microlithization in Northern, Southern and Central Asia. This study may forward the adequate estimation of phenomenon, associated with microliths and early microflaking, newly discovered for the last decade in Mongolia. Here we offer to consider and distinct few terms, before the actual consideration of small laminar blank production in eastern Central and northeast Asia small-blade, bladelet, and microblade production as well as definition of microliths.

\section{Small-blade production}

This term first appeared to describe the industries of middle stage of Upper Paleolithic in Central Siberia's Yenisei River basin, where the targeted laminar blanks were much shorter compared to IUP large blade production [Lisitsyn, 1996, 2000; Akimova, 2008]. "Small blades" present the laminar blanks $2-5 \mathrm{~cm}$ long with retouched both lateral edges and, frequently, transversal edges, that were the tool-marker of Middle Upper Paleolithic between 22,000 11,000 years ago and predefined the targeted blank in knapping technology [Kharevich et al., 2015]. The last was based on reduction of specific small flat unidirectional cores as well as prismatic and narrow-faced cores [Lisitsyn, 1996]. Besides small blades, the number of other blanks was defined there: retouched "small" bladelets (length up to $30 \mathrm{~mm}$ and width 6-10 $\mathrm{mm}$ ) and "medium" bladelets (length 30-50 $\mathrm{mm}$ and width up to $15 \mathrm{~mm}$ ). Afontova Culture assemblages contain large blades as well as microblades with regular parallel dorsal scars with width up to $4 \mathrm{~mm}$ [Abramova, 1979; Lisitsyn, 2000]. The presence of few reduction strategies, targeted to the different kinds of laminar blanks fostered high diversity of terms, but smallblade production is basic definition to characterize the Middle Upper Paleolithic industries with blades no longer than $20-50 \mathrm{~mm}$ and its production from the specifically prepared cores in Middle Siberia.

About the same definition has been used for laminar blanks with length 40-50 mm from Mousterian complex of Combe-Grenal, levels 29-30. These small blades were produced within one reduction strategy together with bladelets from flake-cores up to $40 \mathrm{~mm}$ long [Faivre, 2012]. Therefore, essentially, small blades are defined by the measurements of their length, not width. Several types of cores are character to these industries: subprismatic cores with halfclosed flaking surface, often cylindrical or barrel-like shape; prismatic cores with two striking platforms and two flaking surfaces or one closed flaking surface for bidirectional small blade production; rare narrow-faced cores. The most pronounced feature of these cores is reduced striking platform, oblique to the backside [Kharevich et al., 2015].

\section{Bladelet production}

Bladelets as the by-products appear in Middle Paleolithic, and through time their production isolates oneself from Levallois point and blade production and became the one of the targeted blanks, flaked from specifically prepared cores by the end of that Paleolithic stage [Boëda, Bonilauri, 2006; Pastoors, Tafelmaier, 2010]. Early bladelet industry itself usually is associated with the Aurignacian and Upper Paleolithic in Western Europe and Southwest Asia [Bon, 2006; Boëda et al., 2015]. In eastern Eurasia, bladelet production first appears in Initial Upper Paleolithic assemblages of Obi-Rakhmat in Uzbekistan, Kara Bom and Ust Karakol in the Altai region. Here bladelets were produced from burin-cores and/or narrow-faced cores 
[Krivoshapkin, Kuzmin, Jull, 2010; Zwyns et al., 2012]. Another type of bladelet production is presented in Upper Paleolithic complexes in western Central Asia: Middle and Late stages of the Kulbulak Culture; at Dodekatym-2, layers 5 and 4-2 respectively; Kulbulak, layer 2.1; Shugnou, layer 1 and the Samarkandskaya site [Kolobova et al., 2013]. Carinated bladelet production appeared here about 23,000 years ago and existed along with bladelet production from narrow-faced cores and, together with the toolkit, included triangular microliths, chisellike tools, backed, retouched and Dufour bladelets, were very similar to the Baradostian in the Zagros region (Ibid). Metric parameters of width for targeted removal here are less than $12 \mathrm{~mm}$, uniting bladelets and microblades as well [Kolobova et al., 2011]. Here we regard bladelet production as a complex of special core types, prepared for production of this kind of targeted blanks and its products by itself with width from 6 to $12 \mathrm{~mm}$.

\section{Percussive and pressure microblade production}

Since Northeast Asia is thought to be one place where pressure microblade production emerged [Takakura, 2012; Gómez Coutouly, 2018; Keates, Postnov, Kuzmin, 2019; Song et al., 2019] and includes many various regions with local archaeological terminologies and traditions, it is important to mention it here.

The Russian archaeological tradition still does not have a special term to distinguish percussive and pressure microblade technology. A microblade is a laminar blank, less than 6 $\mathrm{mm}$ long and produced from a variety of specialized microcores, by percussion or pressure. Currently, some researchers are very strict, defining microblade technology as pressure flaking [Pavlenok, 2015; Keates, Postnov, Kuzmin, 2019] and even narrower - flaking from wedgeshaped, prismatic or conical cores [Morlan, 1970], but some still include both techniques in this definition [Gladyshev, 2017; Gladyshev \& Tabarev, 2018]. Technique descriptions are based upon core type or Japanese terminology, e.g. wedge-shaped technology — the Yubetsu technique etc.

The Chinese archaeological tradition did not initially distinguish between definitions of "microblades" and "microliths" [Chen, Wang, 1989]. At the end of the 1970s it was decided to limit the term "microlith" to a narrow range of artifacts - microblades, microblade cores and tools on microblades [An, 1978]. So, the definition of "microlith" means the same as "microblade industry," not "small tools." There are several techniques described for microblade production in China, some are similar to those known in Russian and Japanese archaeology [Chen \& Wang, 1989].

The most complex definitions of techniques, used in microblade technology, are based on archaeological material from Japanese archipelago [Nakazawa et al., 2005; Nakazawa, Akai, 2017; Sato, Tsutsumi, 2007; Takakura, 2012]. At least 7 microblade techniques are known in that region, as well as well-developed approach to distinct obsidian microblades, produced by pressure, indirect percussion and direct percussion [Takakura, 2012]. At the same time, not all techniques indispensably suppose pressure production: obsidian wedge-shaped cores could be utilized by indirect or direct percussion also [Pelegrin, 2003; Takakura, 2012].

For us, the width of laminar blank will be the determinant factor to divide microblades in assemblages. Despite that, in some research the length can be the main parameter, since the ranges of width among laminar blanks overlap [Brunet, 2012]. Supposedly pressure 
microblades, described here, have straight and parallel arises [Inizan et al., 1999] and parallel edges. If some examinations of microblade assemblages fair based upon a several components, e.g. wedge-shaped microcores, microblades and retouched microblades [Keates, Postnov, Kuzmin, 2019], in our case we need to cut this list, and stay with microcores and microblades or retouched microblades only. It is an unavoidable step, because most of the sites in northern Mongolia are workshops, with shorter lists of artifact categories. Microblade industries in Mongolia could be based on wedge-shaped, wedge-shaped on bifaces, conical, semiconical, boat-shaped, cylindrical, and bullet (or pencil-shaped) cores.

\section{Microliths}

Pargeter [2016] points that some of researchers define microliths -artifacts with lengths $2-3 \mathrm{~cm}$ or shorter, produced by any kind of percussion or pressure, and geometric microliths that have a standardized shape (trapezoids, rectangles, triangles, etc.) and made on bladelets, intentionally fragmented, often by microburin or "truncation notch+snap" techniques [Ibid]. Clarkson et al. [2018], following Pargeter [2016] suppose that a "microlith package," consisting of three components - backing, miniaturization, and microblade production from prismatic cores - can be "unpacked," because these components occur independently. They contemplate the convergence of microlithic technology.

It has been supposed that microlithic technology first appeared in Africa about 80-60 ka BP and spread into Southern Asia: specific types of microliths have been distributed in Eastern Africa and Hindustan along the coast of Indian Ocean [Mellars, 2006; Clarkson et al., 2009, 2018; Mishra, Chauhan, Singhvi, 2013; Blinkhorn, 2018]. The earliest evidence of the backed microliths were found on the southern realm of Indian subcontinent in Sri-Lanka. Flake tools with size less than $50 \mathrm{~mm}$ are known in Fa-Hien Lena cave, Sri Lanka, dated to 48-45 ka BP [Wedage et al., 2019].

The other center of possibly independent geometric microlith origin is Levant. Here, in the Epipaleolithic period about 20-10 ka BP there was a tendency to form the tools (backed blades, truncated bladelets, varios geometric microliths and lunates) with invasive and blunt retouch and microburin technique. This trend led to Final Epipaleolithic approach to reshape every small elongated spall into microlith [Belfer-Cohen, Goring-Morris, 2002].

To sum up, intentionally predetermined shape with backing, in addition to arbitrary, but mainly with small size unifies these artifacts, is defined as a microlith. These tools have specific advantages: standardized shape, transportability, availability to be replaced in composite tools and possible usage as the inserts of projectile weapon, that may play significant role in reconstruction of paleoecological conditions.

\section{Discussion}

Mongolia has been considered as a possible place of micropressure origin [Gladyshev, Tabarev, 2018]. Production of the small laminar blanks here has a long history and evolution. We consider this evolution to understand the connections or disconnections between different small blade technologies. Bladelet production in the lithic industries appears in Initial Upper Paleolithic complexes ca. 45-40 cal. ka in Mongolia and Russian Altai (Kara-Bom, Tolbor 4, Tolbor 16) [Derevianko et al., 1998, 2007; Zwyns et al., 2014]. 

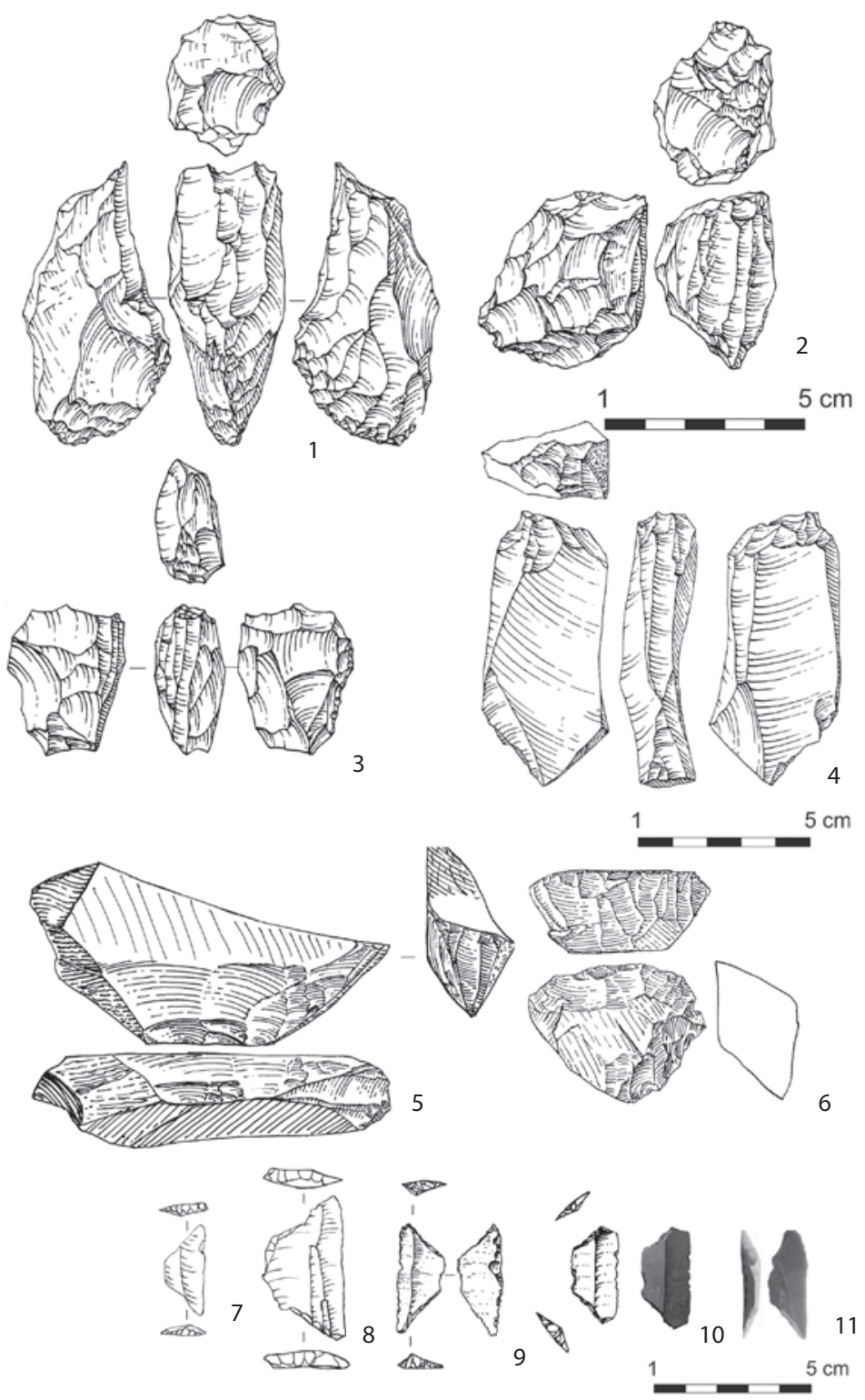

Fig. 1. Selected artifacts from Initial Upper Paleolithic - Late Upper Paleolithic industries of Northern Mongolia: 1-2 - bladelet cores, Tolbor-4, AH5; 3 - bladelet core, Tolbor-4, AH6; 4 - burin-core, Tolbor-4, AH6; 5 - carinated core, Tolbor-4, AH5; 6-carinated core, Tolbor-4, AH4; 7-9 - trapezes, Kharganyn-Gol-5, AH4; 10 - trapeze, Tolbor-21, AH2;

$$
11 \text { - trapeze, Tolbor-4, AH6 }
$$

Рис. 1. Артефакты из индустрии начального - позднего верхнего палеолита Северной Монголии: 1-2 - нуклеусы для пластинок, Толбор-4, гор. 5; 3 - нуклеус для пластинок, Толбор-4, гор. 6; 4 - нуклеус-резец, Толбор-4, гор. 6; 5 - кареноидный нуклеус, Толбор-4, гор. 4; 7-9 - трапеции, Харганын-Гол-5, гор. 4; 10 - трапеция, Толбор-21, гор. 2;

$$
11 \text { - трапеция, толбор-4, гор. } 6
$$


Core types reflect an intentional bladelet production, independent from blade production (Fig. 1.-1-3). The most numerous type of core, aimed to bladelet production, is narrow-faced. Another type represents the series of small flat short cores with one or two striking platforms. This type of cores has rectangular shape and flat cross-section. It was an independent reduction method, because a number of them were left on the initial stage of utilization, with cortex on the flaking surface. The other type is subprismatic / prismatic circular-shaped cores with single or two opposite striking platforms, close to so-called "barrel-shaped" cores. The most remarkable type of bladelet nuclei is burin-core (Fig. 1.-4). Carinated cores are very few (Fig. 1.-5, 6). Having appeared in Northern Mongolia about 38000 BP, this type made a fleeting appearance in later complexes of Tolbor group. Some of carinated cores were retouched on the final stage of its utilization. Retouch is situated on the platform edge, forming the working edge of high end-scraper. Most of these types, except burin-cores, can be found in the Early Upper Paleolithic industries in Northern Mongolia. In the end of this period remarkable tool types appeared in Northern Mongolia - geometric microliths, presented by segments and trapezes (Fig. 1.-7-11). Approximate age of these complexes falls within a range from 30 to $18 \mathrm{cal}$. ka. They were replaced by complexes with pressure microblade production. Considering the chronological gaps between the time being of these technologies, high diversity of technologies, as well as poor presentation of pressure microblade technology, it seems that Mongolia was the transitional territory for multiple populations with different technologies. It is still questionable that any of those technologies originated in this region.

\section{Conclusion}

Our review highlighted wide and, occasionally, controversial spectrum of definition and views, accompanying the research problems of microlithization of lithic tools during the Late Pleistocene in Asia and interpretation of microlithic tools. It is more likely that microlithic technology appeared and disappeared repeatedly. Independent invention of microlithic technology has been supposed for several regions. Mongolia is potentially an important area for understanding of microlithic technology distribution. Here it is more likely that IUP small blade production appeared as the result of direct migration from the Altai Mountains. The presence of specific microlithic technology in the end of MIS3 can not be reliably associated with migration processes or independent origin. We suggest that the Tolbor group of sites in the Middle Selenga basin contains the earliest evidence of its appearance at the territory of southern Siberia and eastern part of Central Asia.

\section{REFERENCES}

Abramova Z. A. Paleolit Eniseya. Afontovskaya kul'tura. [Paleolithic of Enisey. Afontova Culture]. Novosibirsk : Nauka, 1979. 156 p. (In Russ.)

Akimova E. V. Rannesartanskaya industriya melkih plastin $\mathrm{v}$ finale pozdnego paleolita Srednego Eniseya: k probleme formirovaniya arheologicheskih refugiumov [Early Sartan Small Blade Industry in the Final Late Paleolithic of Middle Yenisei: the Problem of Archaeological Refugium Forming]. Problemy biologicheskoj i kulturnoj adaptacii chelovecheskih populyacij. T. 1: Arheologiya. Adaptacionnye strategii drevnego naseleniya Severnoj Evrazii: syr'e i priyomy obrabotki [Problems of Biological and Cultural Adaptation of Human Populations. 
Vol. 1: Archaeology. Adaptation Strategies of the Ancient Population of Northern Eurasia: Raw Materials and Processing Techniques]. SPb. : Nauka, 2008. Pp. 37-47. (In Russ.)

An Zh. The Mesolithic Remains in Hailar - Also on the the Origin and the Tradition of Microliths. Kaogu Xuebao (Chinese Journal of Archaeology). 1978. Vol. 3. Pp. 289-316.

Belfer-Cohen A., Goring-Morris A. N. Why Nicroliths? Microlithization in the Levant. Thinking Small: Global Per-spectives on Microlithic Technologies. Arlington : AP3A, 2002. Pp. 57-68.

Blinkhorn J. Buddha Pushkar Revisited: Technological Variability in Late Palaeolithic Stone Tools at the Thar Desert Margin, India. Journal of Archaeological Science: Reports. 2018. Vol. 20. Pp. 168-182.

Boëda E., Bonilauri S. The Intermediate Paleolithic : the First Bladelet Production 40,000 Years Ago. Anthropologie-International Journal of Human Diversity and Evolution. 2006. Vol. 44 (1). Pp. 75-92.

Boëda E., Bonilauri S., Kaltnecker E., Valladas H., Al-Sakhel H. Un débitage lamellaire au Proche-Orient vers 40000 ans cal BP. Le site d'Umm el Tlel, Syrie central // Lanthropologie. 2015. Vol. 119. Pp. 141-169.

Bon. F. A Brief Overview of Aurignacian Cultures in the Context of the Industries of the Transition from the Middle to the Upper Paleolithic. Towards a Definition of the Aurignacian. Lisbon: Instituto Português de Arqueologia (Trabalhos de Arqueologia 45). 2006. Pp. 133-144.

Brunet, F. The Technique of Pressure Knapping in Central Asia: Innovation or Diffusion? The Emergence of Pressure Blade Making: From Origin to Modern Experimentation. Québec : Springer, 2012. Pp. 307-328.

Chen Ch., Wang X.-Q. Upper Paleolithic Microblade Industries in North China and Their Relationships with Northeast Asia and North America. Arctic Anthropology. 1989. Vol. 2(26). Pp. 127-156.

Clarkson C., Hiscock P., Mackay A., Shipton C. Small, Sharp, and Standardized: Global Convergence in Backed-Microlith Technology. Convergent Evolution in Stone-Tool Technology. Cambridge : MIT Press, 2018. Pp. 175-200.

Clarkson C., Petraglia M., Korisettar R., Haslam M., Boivin N., Crowther A., et al. The Oldest and Longest Enduring Microlithic Sequence in India: 35000 Years of Modern Human Occupation and Change at the Jwalapuram Locality 9 Rockshelter. Antiquity. 2009. Vol. 83(320). Pp. 326-348.

Derevianko A.P., Petrin V.T., Rybin E. P., Chevalkov L. M. Paleoliticheskie komplexy stratificirovannoy chasti stoyanki Kara-Bom (mustye i verkhniy paleolit) [Paleolithic Complexes of the Stratified Part of the Kara-Bom Site (Mousterian/Upper Paleolithic]. Novosibirsk : IAET, 1998. 235 p. (In Russ., English, French).

Derevianko A.P., Zenin A.N., Rybin E.P., Gladyshev S.A., Tsybankov A.A., Olsen J. W., Tseveendorj D., Gunchinsuren, B. The Technology of Early Upper Paleolithic Lithic Reduction in Northern Mongolia: the Tolbor-4 site. Archaeology, Ethnology and Anthropology of Eurasia. 2007. Vol. 29. Pp. 16-38.

Faivre J.-Ph. A Material Anecdote but Technical Reality: Bladelet and Small Blade Production during the Recent Middle Paleolithic at Combe-Grenal Rock Shelter. Lithic Technology. 2012. Vol. 37. Pp. 5-25. 
Gladyshev S. A. Svidetel'stva primeneniya tehniki mikrorasshchepleniya v kompleksah rannego verhnego paleolita mnogoslojnyh stratificirovannyh stoyanok Gobijskogo Altaya [Evidence of Micropercussion Technique in the Complexes of the Early Upper Paleolithic at the Multilayered Stratified Sites in the Gobi Altai]. Problemy arheologii, etnografii, antropologii Sibiri i sopredel'nyh territorij [Problems of Archaeology, Ethnography and Anthropology of Siberia and Neighboring territories]. Novosibirsk : Izd-vo In-ta arheologii i etnografii SO RAN, 2017. Vol. 23. Pp. 202-205 (In Russ.).

Gladyshev S. A., Tabarev A. V. Nekotorye problemy izucheniya mikroplastinchatogo rasshchepleniya v rannem verhnem paleolite Severnoj Mongolii [Some Problems of Studies of Microblade Percussion in the Early Upper Paleolithic of Norhtern Mongolia]. Teoriya i praktika arheologicheskih issledovanij [Theory and Practice of Archaeological Research]. 2017. Vol. 17 (1). Pp. 154-166. (In Russ.)

Gladyshev S. A., Tabarev A. V. Mikroplastinchatoe rasshcheplenie v rannem verhnem paleolite Mongolii [Microblade Production in the Early Upper Paleolithic of Mongolia]. Stratum Plus : Archaeology and Cultural Anthropology. 2018. No. 1. Pp. 339-351. (In Russ.)

Gómez Coutouly Y. A. The emergence of pressure knapping microblade technology in Northeast Asia. Radiocarbon. 2018. Vol. 60. Pp. 821-855.

Inizan M.-L., Reduron-Ballinger M., Roche H., Tixier J. Technology and Terminology of Knapped Stone. Nanterre : C.R.E.P., 1999. 191 p.

Keates S. G., Postnov A. V., Kuzmin, Y. V. Towards the Origin of Microblade Technology in Northeastern Asia. Vestnik of Saint Petersburg University. History. 2019. Vol. 64. Pp. 390-414.

Kharevich V. M., Akimova E. V., Stasyuk I. V., Tomilova E. A. Tehnologiya proizvodstva plastin v kamennoj industrii kul'turnogo sloya 19 stoyanki Listvenka [Blade Production Technology in the Industry of Layer 19 of the Listvenka Site]. Stratum Plus. Cultural Anthropology and Archaeology. 2015. No. 1. Pp. 321-331. (In Russ.)

Kolobova K.A., Flas D., Derevianko A. P., Pavlenok K. K., Islamov U. I., Krivoshapkin A. I. The Kulbulak Bladelet Tradition in The Upper Paleolithic of Central Asia. Archaeology, Ethnology and Anthropology of Eurasia. 2013. Vol. 41 (2). Pp. 2-25. https://doi.org/10.1016/j. aeae.2013.11.002.

Kolobova K. A., Krivoshapkin A. I., Derevyanko A. P., Islamov U.I. Dodekatym-2 Paleolithic site (Uzbekistan) // Archaeology, Ethnology, and Anthropology of Eurasia. 2011. Vol. 48 (4). Pp. 2-12.

Krivoshapkin A., Kuzmin Y., Jull A. J. Chronology of the Obi-Rakhmat Grotto (Uzbekistan): First Results on the Dating and Problems of the Paleolithic Key Site in Central Asia // Radiocarbon. 2010. Vol. 52 (2-3). Pp. 549-554.

Kuhn S., Elston R. G. Introduction: Thinking Small Globally. Thinking Small: Global Perspectives on Microlithization. Archaeological Paper No. 12. Washington : American Anthropological Association, 2002. Pp. 1-8.

Lisitsyn N. F. Pozdnij paleolit Chulymo-Enisejskogo mezhdurech'ya [Late Paleolithic of Chulym-Enisej Interfluve]. Trudy IIMK RAN [Proceedings of the IIMK RAN]. SanktPetersburg : Peterb. vostokovedenie, 2000. Vol. 2. 230 p. (In Russ.)

Lisitsyn N. F. Srednij etap pozdnego paleolita Sibiri [Middle Stage of Siberian Late Paleolithic]. Rossijskaya arheologiya. 1996. №4. Pp. 5-17. (In Russ.) 
Mao X., Zhang H., Qiao S., Liu Y., Chang F., Xie P., Zhang M., Wang T., Li M., Cao P., Yang R., Liu F., Dai Q., Feng X., Ping W., Lei C., Olsen J.W., Bennett E. A., Fu Q. The Deep Population History of Northern East Asia from the Late Pleistocene to the Holocene. Cell. 2021. Vol. 184. Pp. 1-11. https://doi.org/10.1016/j.cell.2021.04.040.

Mellars P. Why Did Modern Human Populations Disperse from Africa 60,000 Years Ago? A New Model. Proceedings of the National Academy of Sciences. 2006. Vol. 103. P. 9381.

Mishra S., Chauhan N., Singhvi A. K. Continuity of Microblade Technology in the Indian Subcontinent Since 45 ka: Implications for the Dispersal of Modern Humans. PLoS ONE. 2013. Vol. 8(7) Pp. e69280. https://doi.org/10.1371/journal.pone.0069280

Morlan R. E. Wedge-shaped Core Technology in Northern North America. Arctic Anthropology. 1970. Vol. 7(2). Pp. 17-37.

Nakazawa Y., Akai F. Late-Glacial Bifacial Microblade Core Technologies in Hokkaido: An Implication of Human Adaptation along the Northern Pacific Rim. Quaternary International. 2017. Vol. 442. Pp. 43-54. https://doi: 10.1016/j.quaint.2016.07.019.

Nakazawa Y., Izuho M., Takakura J., Yamada S. Toward an Understanding of Technological Variability in Microblade Assemblages in Hokkaido. Japan. Asian Perspectives. 2005. Vol. 44. Pp. 276-292.

Pargeter J. Lithic Miniaturization in Late Pleistocene Southern Africa. Journal of Archaeological Science: Reports. 2016. Vol. 1010. Pp. 221-236.

Pastoors A., Tafelmaier Y. Bladelet Production, Core Reduction Strategies, and Efficiency of Core Configuration at the Middle Palaeolithic site Balver Höhle (North Rhine Westphalia, Germany). Quartär. 2010. Vol. 57. Pp. 25-41.

Pavlenok G. D. Tehnologiya izgotovleniya klinovidnyh nukleusov v selenginskoj kul'ture Zapadnogo Zabajkal'ya (po materialam stoyanki Ust'-Kyahta-3) [Technology of WedgeShaped Cores Production in the Selenga Culture of Western Tansbaikalia]. Izvestiya Altajskogo gosudarstvennogo universiteta. Ser.: Istoricheskie nauki i arheologiya. 2015. No. 3/2 (87). Pp. 178-184. (In Russ.)

Pelegrin J. Blade Making Techniques from the Old World: Insights and Applications to Mesoamerican Obsidian Lithic Technology. Mesoamerican Lithic Technology: Experimentation and Interpretation. Salt Lake City : The University of Utah Press, 2003. Pp. 55-71.

Rybin E. P., Khatsenovich A.M., Zwins N., Gunchinsurehn B., Paine C., Bolorbat Ts., Anojkin A. A., Kharevich V.M., Odsuren D., Margad-Erdene G. Stratigrafiya i kul'turnaya posledovatel'nost' stoyanki Tolbor-21 (Severnaya Mongoliya): itogi rabot 2014-2016 godov i dal'nejshie perspektivy issledovanij [Stratigraphy and Cultural Sequence of the Tolbor 21 Site (Northern Mongolia): the Results of the 2014-2016 Excavation Campaigns and Perspectives of Further Investigations]. Teoriya i praktika arheologicheskih issledovanij [Theory and Practice of Archaeological Research]. 2017. Vol. 15. No. 4 (20). Pp. 158-168. (In Russ.)

Sato H., Tsutsumi T. The Japanese Microblade Industries: Technology, Raw Material Procurement, and Adaptations. Origin and Spread of Microblade Technology in Northern Asia and North America. Burnaby (BC) : Archaeology Press, Simon Fraser University, 2007. Pp. 57-78.

Sollberger J. B., Patterson L. W. Prismatic Blade Replication. American Antiquity. 1976. Vol. 41. Pp. 517-531. 
Song Y., Grimaldi S., Santaniello F., Cohen D. J., Shi J., Bar-Yosef O. Re-thinking the Evolution of Microblade Technology in East Asia: Techno-Functional Understanding of the Lithic Assemblage from Shizitan 29 (Shanxi, China). PLoS One. 2019. Vol. 14 (2). P. e0212643.

Soriano S., Villa P., Wadley L. Blade Technology and Tool Forms in the Middle Stone Age of South Africa: the Howiesons Poort and Post-Howiesons Poort at Rose Cottage Cave. Journal of Archaeological Science. 2007. Vol. 34 (2007). Pp. 681-703.

Takakura J. Emergence and Development of the Pressure Microblade Production: a View from the Upper Paleolithic of Northern Japan. The Emergence of Pressure Blade Making. Québec : Springer, 2012. Pp. 285-306.

Taylor W. E. A Distinction between Blades and Microblades in the American Arctic. American Antiquity. 1962. Vol. 27. Pp. 425-426.

Tixier J. Typologie de l'Epipaléolithique du Maghreb. Mémoires du Centre de Recherches anthropologiques et préhistoriques et ethnographiques 2. Paris : Arts et Métiers graphiques, 1963. $212 \mathrm{p}$.

Wedage O., Picin A., Blinkhorn J., Douka K., Deraniyagala S., Kourampas N., Perera N., Simpson I., Boivin N., Petraglia M., Roberts P. Microliths in the South Asian Rainforest 45-4 ka: New Insights from Fa-Hien Lena Cave, Sri Lanka. PLoS ONE. 2019. Vol. 14(10). P. e0222606. https://doi.org/10.1371/journal.pone.0222606

Zwyns N., Gladyshev S. A., Gunchinsuren B., Bolorbat T., Flas D., Tabarev A. V., Dogandzic T., Gillam G. C., Khatsenovich A.M., Odsuren D., Purevjal K.-E., Richards M., Stewart J., Talamo S. The Open-Air Site of Tolbor 16 (Northern Mongolia): Preliminary Results and Perspectives. Quaternary International. 2014. Vol. 347. Pp. 53-65.

Zwyns N., Rybin E. P., Hublin J.-J., Derevianko A. P. Burin-Core Technology and Laminar Reduction Sequence in the Initial Upper Paleolithic from Kara-Bom (Gorny-Altai, Siberia). Quaternary International. 2012. Vol. 259. P. 33-47.

\section{БИБЛИОГРАФИЧЕСКИЙ СПИСОК}

Абрамова 3. А. Палеолит Енисея. Афонтовская культура. Новосибирск : Наука, 1979. $156 \mathrm{c}$.

Акимова Е. В. Раннесартанская индустрия мелких пластин в финале позднего палеолита Среднего Енисея: к проблеме формирования археологических рефугиумов // Проблемы биологической и культурной адаптации человеческих популяций. Т. 1: Археология. Адаптационные стратегии древнего населения Северной Евразии: сырье и приемы обработки. СПб. : Наука, 2008. С. 37-47.

Гладышев С. А. Свидетельства применения техники микрорасщепления в комплексах раннего верхнего палеолита многослойных стратифицированных стоянок Гобийского Алтая // Проблемы археологии, этнографии, антропологии Сибири и сопредельных территорий. Новосибирск : Изд-во Ин-та археологии и этнографии СО РАН, 2017. T. XXIII. C. 202-205.

Гладышев С. А., Табарев А. В. Некоторые проблемы изучения микропластинчатого расщепления в раннем верхнем палеолите Северной Монголии // Теория и практика археологических исследований. 2017. Т. 17. № 1. С. 154-166. 
Гладышев С.А., Табарев А.В. Микропластинчатое расщепление в раннем верхнем палеолите Монголии // Stratum Plus: Archaeology and Cultural Anthropology. 2018. № 1. C. 339-351.

Лисицын Н.Ф. Средний этап позднего палеолита Сибири // Российская археология. 1996. № 4. С. 5-17.

Лисицын Н.Ф. Поздний палеолит Чулымо-Енисейского междуречья // Тр. ИИМК РАН. СПб. : Петерб. востоковедение, 2000. Т. 2. 230 с.

Павленок Г. Д. Технология изготовления клиновидных нуклеусов в селенгинской культуре Западного Забайкалья (по материалам стоянки Усть-Кяхта-3) // Известия Алтайского государственного университета. Сер.: Исторические науки и археология. 2015. № 3/2 (87). С. 178-184.

Рыбин Е. П., Хаценович А. М., Звинс Н., Гунчинсурэн Б., Пэйн К., Болорбат Ц., Анойкин А. А., Харевич В. М., Одсурен Д., Маргад-Эрдэнэ Г. Стратиграфия и культурная последовательность стоянки Толбор-21 (Северная Монголия): итоги работ 2014-2016 годов и дальнейшие перспективы исследований // Теория и практика археологических исследований. 2017. Т. 15. № 4 (20). С. 158-168.

Харевич В. М., Акимова Е. В., Стасюк И. В., Томилова Е. А. Технология производства пластин в каменной индустрии культурного слоя 19 стоянки Лиственка // Stratum Plus: Культурная антропология и археология. Санкт-Петербург; Кишинев; Одесса; Бухарест. 2015. № 1. C. 321-331.

An Zh. The Mesolithic Remains in Hailar - Also on the the Origin and the Tradition of Microliths. Kaogu Xuebao (Chinese Journal of Archaeology). 1978. Iss. 3. Pp. 289-316.

Belfer-Cohen A., Goring-Morris A. N. Why microliths? Microlithization in the Levant // Thinking Small: Global Per-spectives on Microlithic Technologies. 2002. Arlington: AP3A. Pp. 57-68.

Blinkhorn J. Buddha Pushkar revisited: Technological variability in Late Palaeolithic stone tools at the Thar Desert margin, India // Journal of Archaeological Science: Reports. 2018. Vol. 20. Pp. 168-182.

Boëda E., Bonilauri S. The Intermediate Paleolithic : the first bladelet production 40,000 years ago // Anthropologie-International Journal of Human Diversity and Evolution. 2006. Vol. 44 (1). Pp.75-92.

Boëda E., Bonilauri S., Kaltnecker E., Valladas H., Al-Sakhel H. Un débitage lamellaire au Proche-Orient vers 40000 ans cal BP. Le site d'Umm el Tlel, Syrie centrale // Lanthropologie. 2015. Vol. 119. Pp. 141-169.

Bon F. A brief overview of Aurignacian cultures in the context of the industries of the transition from the middle to the upper Paleolithic // Towards a Definition of the Aurignacian. Lisbon : Instituto Português de Arqueologia (Trabalhos de Arqueologia 45), 2006. Pp. 133-144.

Brunet F. The Technique of Pressure Knapping in Central Asia: Innovation or Diffusion? // The Emergence of Pressure Blade Making: From Origin to Modern Experimentation. Québec: Springer. 2012. Pp. 307-328.

Clarkson C., Petraglia M., Korisettar R., Haslam M., Boivin N., Crowther A., et al. The oldest and longest enduring microlithic sequence in India: 35000 years of modern human 
occupation and change at the Jwalapuram Locality 9 rockshelter // Antiquity. 2009. Vol. 83(320). Pp. 326-348.

Clarkson C., Hiscock P., Mackay A., Shipton C. Small, Sharp, and Standardized: Global Convergence in Backed-Microlith Technology // Convergent Evolution in Stone-Tool Technology. Cambridge : MIT Press, 2018. Pp. 175-200.

Chen Ch., Wang X.-Q. Upper Paleolithic microblade industries in North China and their relationships with Northeast Asia and North America // Arctic Anthropology. 1989. Vol. 2(26). Pp. 127-156.

Derevianko A.P., Petrin V.T., Rybin E. P., Chevalkov L. M. Paleoliticheskie komplexy stratificirovannoy chasti stoyanki Kara-Bom (mustye i verkhniy paleolit) [Paleolithic Complexes of the Stratified Part of the Kara-Bom Site (Mousterian/Upper Paleolithic]. Novosibirsk : IAET, 1998. 235 p. (In Russian, English, French).

Derevianko A.P., Zenin A.N., Rybin E.P., Gladyshev S. A., Tsybankov A.A., Olsen J.W., Tseveendorj D., Gunchinsuren B. The technology of early Upper Paleolithic lithic reduction in Northern Mongolia: the Tolbor-4 site // Archaeology, Ethnology and Anthropology of Eurasia. 2007. Vol. 29. Pp. 16-38.

Faivre J.-Ph. A material anecdote but technical reality: bladelet and small blade production during the recent Middle Paleolithic at Combe-Grenal rock shelter // Lithic Technology. 2012. Vol. 37. Pp. 5-25.

Gómez Coutouly Y.A. The emergence of pressure knapping microblade technology in Northeast Asia // Radiocarbon. 2018. Vol. 60. Pp. 821-855.

Inizan M.-L., Reduron-Ballinger M., Roche H., Tixier J. Technology and Terminology of Knapped Stone. Nanterre : C.R.E.P., 1999. 191 p.

Kolobova K. A., Krivoshapkin A. I., Derevyanko A. P., Islamov U. I. Dodekatym-2 Paleolithic site (Uzbekistan) // Archaeology, ethnology and anthropology of Eurasia. 2011. Vol. 48 (4). Pp. 2-12.

Kolobova K.A., Flas D., Derevianko A. P., Pavlenok K. K., Islamov U. I., Krivoshapkin A. I. The Kulbulak Bladelet Tradition in The Upper Paleolithic of Central Asia // Archaeology, Ethnology and Anthropology of Eurasia. 2013. Vol. 41 (2). Pp. 2-25. https://doi.org/10.1016/j. aeae.2013.11.002.

Kuhn S., Elston R.G. Introduction: Thinking Small Globally. // Thinking small: Global perspectives on microlithization. Archaeological Paper No. 12. Washington : American Anthropological Association, 2002. Pp. 1-8.

Keates S. G., Postnov A. V., Kuzmin Y.V. Towards the origin of microblade technology in Northeastern Asia // Vestnik of Saint Petersburg University. History. 2019. Vol. 64. Pp. 390-414.

Krivoshapkin A., Kuzmin Y., Jull A. J. Chronology of the Obi-Rakhmat grotto (Uzbekistan): first results on the dating and problems of the Paleolithic key site in Central Asia // Radiocarbon. 2010. Vol. 52. (2-3). Pp. 549-554.

Mao X., Zhang H., Qiao S., Liu Y., Chang F., Xie P., Zhang M., Wang T., Li M., Cao P., Yang R., Liu F., Dai Q., Feng X., Ping W., Lei C., Olsen J.W., Bennett E.A., Fu Q. The deep population history of northern East Asia from the Late Pleistocene to the Holocene // Cell. 2021. Vol. 184. Pp. 1-11. https://doi.org/10.1016/j.cell.2021.04.040. 
Mellars P. Why did modern human populations disperse from Africa 60,000 years ago? A new model // Proceedings of the National Academy of Sciences. 2006. Vol. 103. P. 9381.

Mishra S., Chauhan N., Singhvi A.K. Continuity of Microblade Technology in the Indian Subcontinent Since $45 \mathrm{ka}$ : Implications for the Dispersal of Modern Humans // PLoS ONE. 2013. Vol. 8(7) Pp. e69280. https://doi.org/10.1371/journal.pone.0069280

Morlan R. E. Wedge-shaped core technology in northern North America // Arctic Anthropology. 1970. Vol. 7(2). Pp. 17-37.

Pargeter J. Lithic miniaturization in late Pleistocene southern Africa // Journal of Archaeological Science: Reports. 2016. Vol. 1010. Pp. 221-236.

Pastoors A., Tafelmaier Y. Bladelet production, core reduction strategies, and efficiency of core configuration at the Middle Palaeolithic site Balver Höhle (North Rhine Westphalia, Germany) // Quartär. 2010. Vol. 57. Pp. 25-41.

Pelegrin J. Blade Making Techniques from the Old World: Insights and Applications to Mesoamerican Obsidian Lithic technology. // Mesoamerican Lithic Technology: Experimentation and Interpretation. Salt Lake City : The University of Utah Press, 2003. Pp. 55-71.

Nakazawa Y., Akai F. Late-Glacial Bifacial Microblade Core Technologies in Hokkaido: An Implication of Human Adaptation along the Northern Pacific Rim // Quaternary International. 2017. Vol. 442. Pp. 43-54, https://doi: 10.1016/j.quaint.2016.07.019.

Nakazawa Y., Izuho M., Takakura J., Yamada S. Toward an understanding of technological variability in microblade assemblages in Hokkaido, Japan // Asian Perspectives. 2005. Vol. 44. Pp. 276-292.

Sato H., Tsutsumi T. The Japanese microblade industries: technology, raw material procurement, and adaptations // Origin and Spread of Microblade Technology in Northern Asia and North America. Burnaby (BC): Archaeology Press, Simon Fraser University. 2007. Pp. 57-78.

Song Y., Grimaldi S., Santaniello F., Cohen D.J., Shi J., Bar-Yosef O. Re-thinking the evolution of microblade technology in East Asia: Techno-functional understanding of the lithic assemblage from Shizitan 29 (Shanxi, China) // PLoS One. 2019. Vol. 14 (2). P. e0212643.

Takakura J. Emergence and development of the pressure microblade production: a view from the Upper Paleolithic of Northern Japan // The Emergence of Pressure Blade Making. Québec : Springer, 2012. Pp. 285-306.

Sollberger J. B., Patterson L. W. Prismatic blade replication // American Antiquity. 1976. Vol. 41. Pp. 517-531.

Soriano S., Villa P., Wadley L. Blade Technology and Tool Forms in the Middle Stone Age of South Africa: the Howiesons Poort and Post-Howiesons Poort at Rose Cottage Cave // Journal of Archaeological Science. 2007. Vol. 34 (2007). Pp. 681-703.

Taylor W.E. A distinction between blades and microblades in the American Arctic // American Antiquity. 1962. Vol. 27. Pp. 425-426.

Tixier J. Typologie de l'Épipaléolithique du Maghreb. Mémoires du Centre de recherches anthropologiques, préhistoriques et ethnographiques 2. Paris : Arts et Métiers graphiques, 1963. $212 \mathrm{p}$. 
Wedage O., Picin A., Blinkhorn J., Douka K., Deraniyagala S., Kourampas N., Perera N., Simpson I., Boivin N., Petraglia M., Roberts P. Microliths in the South Asian rainforest 45-4 ka: New insights from Fa-Hien Lena Cave, Sri Lanka // PLoS ONE. 2019. Vol. 14(10). P. e0222606. https://doi.org/10.1371/journal.pone.0222606

Zwyns N., Rybin E. P., Hublin J.-J., Derevianko A.P. Burin-core technology and laminar reduction sequence in the initial Upper Paleolithic from Kara-Bom (Gorny-Altai, Siberia) // Quaternary International. 2012. Vol. 259. P. 33-47.

Zwyns N., Gladyshev S. A., Gunchinsuren B., Bolorbat T., Flas D., Tabarev A. V., Dogandzic T., Gillam G. C., Khatsenovich A. M., Odsuren D., Purevjal K.-E., Richards M., Stewart J., Talamo S. The open-air site of Tolbor 16 (Northern Mongolia): preliminary results and perspectives // Quaternary International. 2014. Vol. 347. Pp. 53-65.

\section{INFORMATION ABOUT THE AUTHORS / ИНФОРМАЦИЯ ОБ АВТОРАХ}

Arina Mikhailovna Khatsenovich, Candidate of Historical Sciences, Senior Researcher at the Institute of Archaeology and Ethnography SB RAS, Novosibirsk, Russian Federation.

Хаценович Арина Михайловна, кандидат исторических наук, старший научный сотрудник Института археологии и этнографии СО РАН, г. Новосибирск, Российская Федерация.

Evgeny Pavladievich Rybin, Doctor of Historical Sciences, Senior Researcher at the Institute of Archaeology and Ethnography SB RAS, Novosibirsk, Russian Federation.

Рыбин Евгений Павладьевич, доктор исторических наук, старший научный сотрудник Института археологии и этнографии СО РАН, г. Новосибирск, Российская Федерация.

Margad-Erdene Ganbold, PhD student of Novosibirsk State University, Novosibirsk, Russian Federation.

Ганболд Маргад-Эрдэнэ, аспирант Новосибирского государственного университета, г. Новосибирск, Российская Федерация.

Dashzeveg Bazargur, Candidate of Historical Sciences, Researcher at the Institute of Archaeology MAN, Ulaanbaatar, Mongolia.

Базаргур Дашцевег, кандидат исторических наук, старший научный сотрудник Института археологии МАН, г. Улан-Батор, Монголия.

Материал поступил в редколлегию 08.06. 2021.

Статья принята в номер 30.08.2021. 